\title{
Fine violins as an alternative investment: Strings attached?
}

Received (in revised form): 13th December, 2007

\section{R.A.J. Campbell}

completed her PhD on risk management in international financial markets at Erasmus University, Rotterdam in 2001 . She currently works at the University of Maastricht as an assistant professor of finance. Her work has been published in a number of leading journals, including the Journal of International Money and Finance, Journal of Banking and Finance, Financial Analysts Journal, Journal of Portfolio Management, Journal of Empirical Finance, Journal of Risk and Derivatives Weekly. She teaches for Euromoney Financial Training on art investment and works as an independent economic advisor for The Fine Art Fund in London, and for Fine Art Wealth Management, UK. She currently is a member of the supervisory board of ARTESTATE GmbH, based in Germany.

\begin{abstract}
The continual search to reap higher risk-adjusted returns has led to a number of highly alternative assets to be considered for financial investment purposes. Recently, a number of funds have emerged to indirectly invest in the arts sector. The focus has been on fine art, wine and more recently into the possibility of investing into other collectible items and memorabilia. One such area is musical instruments. In this paper, we take a look at the violin sector in particular, which has shown steady annual growth in market value over the past half century; fuelled by a combination of a shortage in supply at the high end of the market and a continued increase in global demand. Using data collected from auction houses and private dealers, we analyse the risk-return characteristics of the violin sector, compare it to other financial assets and assess the implications for portfolio diversification and the ability of pension houses to benefit from this sector.
\end{abstract}

Pensions (2008) 13, 89-96. doi:10.1057/palgrave.pm.5950065

Keywords: art markets, risk and return, portfolio optimisation

\section{Introduction}

The violin sector may at first sight appear an obscure sector of financial investment. However, with prices at the high-end instrument market reaching over $\$ 3 \mathrm{~m}^{1}$ and a recent hedge fund The Fine Violins Fund - pledging at least $\$ 26 \mathrm{~m}$ into old violins there is a growing interest in the market as a means to reaping high returns.

The market for high-end musical instruments is similar to investments in fine art and wine, with return series showing little correlation with other financial asset classes. Although returns are moderate, the low correlation results in an appealing means of diversifying an investment portfolio to achieve the highest risk-adjusted returns.

Correspondence: R.A.J. Campbell, Finance Department, LIFE/ Maastricht University, PO Box 616, 6200MD Maastricht, The Netherlands. Tel: + 31433884827 ;

Fax: +31433884875 ;

E-mail: R.Campbell@FINANCE.unimaas.nl
In this paper, we analyse the violin sector as a potential avenue for alternative investments. In the next section we look at the data and methodology of the price series available. In the subsequent section we focus on the violin sector as a means of portfolio diversification against a number of alternative financial asset classes. In the penultimate section we look at the implications for the pension sector for an investment into the fine violin sector. The final section IV concludes.

\section{Data and methodology}

To estimate the average return for musical instruments, we look at repeat sales data, and estimate an average annual rate of return for violins specifically.

A leading violin dealer, Florian Leonhard, has compiled a sector price index, which includes around 100 constituent instruments. The data 
are based on both auction house sales and data collected from private dealers. The index is comprised of violins at the high end of the market that are sold at repeated intervals on the market. The average period between transactions is seven years. The market is therefore highly illiquid which leads to a smoothing in the subsequent annual returns between sales. The index starts in 1945 and data are available on an annual basis.

The second source of data is provided by Art Market Research. The data unfortunately only starts in 1986 and stops in 2001. Average prices are used, and are then smoothed by a three-month moving average. We include these indices as they give us an alternative indication of price developments over time. The series include Italian, English and French violins, with a total number of 4,443 transactions for violins. The index is comprised of the central 80 per cent of transaction data from sales collected from auction houses only.

In Figure 1, we compare the data for the various indices over the period 1986 until 2001 for the AMR data, and until December 2006 for Florian Leonhard. For comparison we have rebased the series to 1000 in 1986 . We see a general upward movement in the price indices over time.
There are however a number of issues concerning the data, which lead to difficulties in estimation of risk-adjusted returns which need to be taken into careful consideration.

\section{Selection bias}

First, there is a spurious bias in the data collected. Naturally only those violins reaching auction or sold privately via a dealer are included in the data series. This upward bias in the prices reached for famous musical instruments brought into the marketplace is offset, albeit to a small degree, by forced sales which bring many unpopular or untimely items up for sale. ${ }^{2}$ This selection bias is common in many other areas of heterogeneous goods markets, notably in the arts sector, however is also common to real-estate and is noted by Stein $^{3}$ and Goetzman ${ }^{4}$ as a concern in estimating the price return over time. Obviously, this is a cause for concern in both indices looked at as it occurs in both types of indices compiled here.

\section{Market illiquidity}

A second concern is the significant smoothing of prices that are derived in the index methodology. Observation of the volatility of the index for

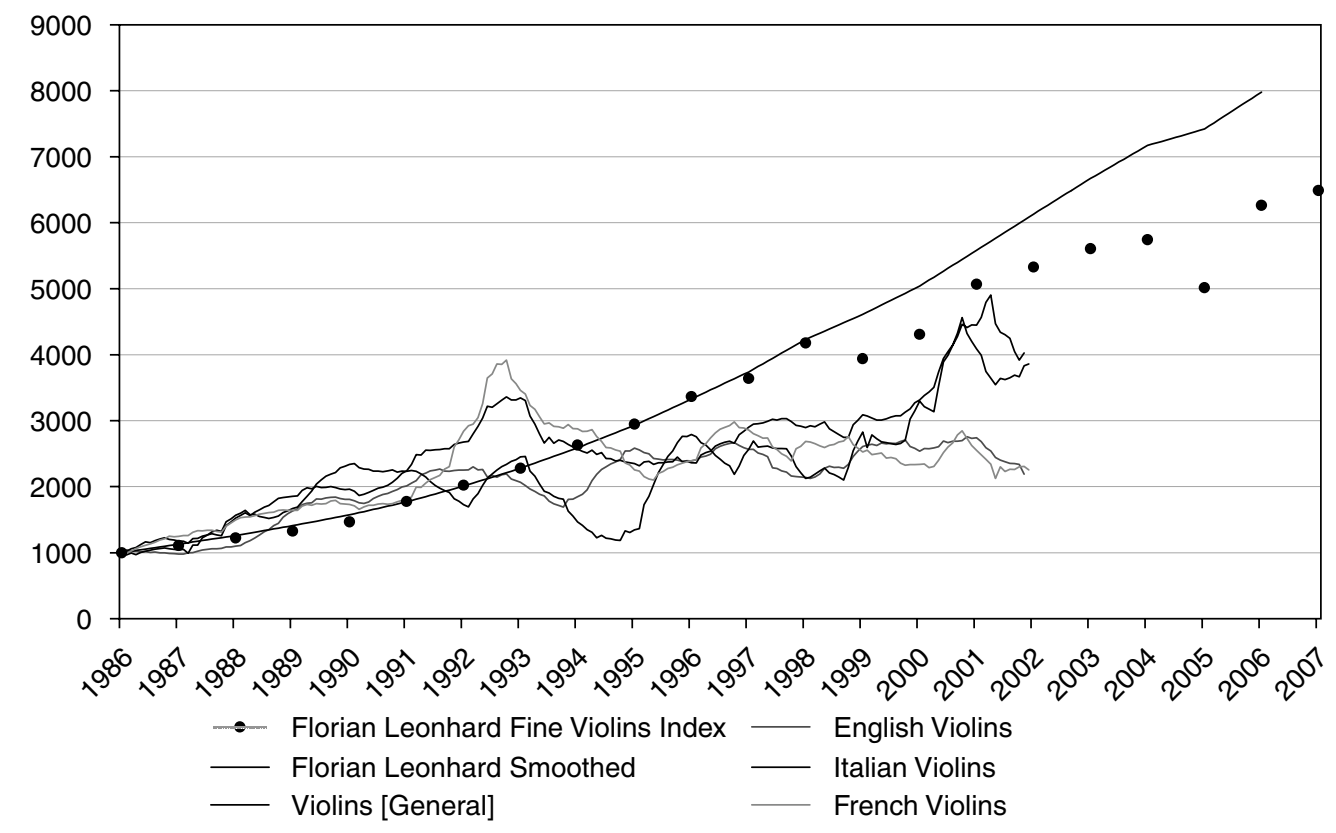

Figure 1: Fine violin indices

Data is provided by Florian Leonhard Fine Violins Index, from January 1986 to December 2006 and Art Market Research (Central 80 per cent) from January 1986 to December 2001. 
prices over time would lead an investor to the belief that violin price returns contain only a low element of risk, as the variation in price is small. This however, is unwarranted, as the smoothed series occurs because of transactions occurring at longer intervals than the frequency of the index. This means that when taking annual averages the data appear to have less volatility than would be the case if items were sold at auction more frequently. The actual risk is therefore much higher to the investor than at first glance and needs to be accounted for. In fact, the very nature of an illiquid market increases the risk, as there is only likely to be a small number of buyers when items appear on the market for sale. Furthermore, illiquidity risk can be great and should also be accounted for. This issue is common to other types of appraisal-based financial assets. Therefore, the data series need to be desmoothed. We follow the methodology of Okunev and White ${ }^{5}$ also used by Campbell ${ }^{6}$ for fine art, and commonly used in the real-estate finance literature and for hedge fund returns. To desmooth the data, we take into account the degree of autocorrelation that the return series exhibits. Significant positive autocorrelation means that the series suffers from appearing less volatile than the true data generating process underlying the return structure. We find that desmoothing the series using the Okunev and White approach leads to a substantial increase in the price risk, with volatility increasing from 2.7 per cent, which seems highly unrealistic to 8.41 per cent, which is much more in line with the volatility of the AMR data. ${ }^{7}$
In Table 1, we provide summary statistics on the Violin sector using the Florian Leonhard Fine Violins Index and average price data from Art Market Research.

The slightly higher average returns obtained by the Florian Leonhard Fine Violins Index is likely to be due to the focus on the high end of the market for fine violins. It would appear that the average returns made in the top end of the market are slightly greater than taking the overall market as a whole.

Taking into account the upward bias in the size of the returns, we could expect a lower average return than generated here. The exact reduction is hard to estimate, and depends highly on the prognoses for the continued fashion for a class of a particular violin. The same occurs in the estimation for expected returns for fine wine, artworks, and of course in equity markets, as well.

Secondly, the risks are greater than captured in the original index, due to the illiquid nature of the market, results in a worsening of the riskadjusted returns in practice from a buy-and-hold strategy in the fine violin sector. The desmoothing procedure increases the volatility by a significant amount, and should capture the true underlying volatility in the market. A further reduction in the average returns occurs from the significant transaction costs that are incurred when buying and selling at auction. However, in relative terms, the underlying volatility of the ine violin sector is about half that of public equities resulting at first glance in a superior Sharpe ratio.

Table 1: Summary statistics

\begin{tabular}{|c|c|c|c|c|c|c|}
\hline & $\begin{array}{l}\text { Florian } \\
\text { Leonhard } \\
\text { smooth }\end{array}$ & $\begin{array}{l}\text { Florian } \\
\text { Leonhard } \\
\text { desmooth }\end{array}$ & $\begin{array}{l}\text { Violins } \\
\text { general }\end{array}$ & $\begin{array}{l}\text { English } \\
\text { violins }\end{array}$ & $\begin{array}{l}\text { French } \\
\text { violins }\end{array}$ & $\begin{array}{l}\text { Italian } \\
\text { violins }\end{array}$ \\
\hline Average annual return & $11.1 \%$ & $9.64 \%$ & $8.34 \%$ & $5.04 \%$ & $4.91 \%$ & $8.80 \%$ \\
\hline $\begin{array}{l}\text { Average annual } \\
\text { standard deviation }\end{array}$ & $2.7 \%$ & $8.41 \%$ & $8.66 \%$ & $7.48 \%$ & $10.13 \%$ & $15.18 \%$ \\
\hline Average monthly return & 0.009 & - & 0.007 & 0.004 & 0.004 & 0.007 \\
\hline $\begin{array}{l}\text { Average monthly } \\
\text { standard deviation }\end{array}$ & 0.002 & - & 0.025 & 0.022 & 0.029 & 0.044 \\
\hline Skewness & -1.154 & -0.871 & 0.215 & 0.018 & 0.417 & 0.977 \\
\hline Kurtosis & 1.046 & 1.737 & 2.001 & 1.389 & 2.595 & 3.735 \\
\hline
\end{tabular}

Florian Leonhard Fine Violins Index and Art Market Research Data on English, French and Italian violins using monthly data from January 1986 until December 2006. 


\section{Transaction costs}

Items sold at auction typically include a 20-25 per cent transaction fee, whereas a private dealer's fee is much lower at only 5-10 per cent. In the analysis, we have not accounted for these high fees. It would be appropriate to reduce the expected return on violins in a portfolio optimisation model according to the size of the transaction costs. Depending on whether a dynamic strategy is held or whether a buy-andhold strategy is undertaken will make a difference in the resounding assumption as to the size of the transaction costs. If a longer time interval is used for the investment period, then the transaction costs are reduced substantially by the length of the holding period.

\section{Market inefficiencies}

The presence of many market inefficiencies in the arts markets, and also in particular the musical instrument market leaves room for much higher returns to be made than estimated from a sheer buy-and-hold strategy which is captured in the indices above. A major source of market inefficiency is the presence of asymmetric information in the market.

\section{Indirect investment - violin funds}

The ability of fund managers, who have an insight into the market inefficiencies, and who are also able to negotiate lower fees when trading fine violins means that the transaction costs incurred are less to a fine violin fund than to the direct investor in similar musical instruments.

\section{Portfolio diversification}

Having looked at the average annual price series returns for violins in the previous section, we now turn to the possibility of an investor diversifying his portfolio into the fine violin sector. The analysis depends crucially on the estimate for the correlation between fine violins prices and other asset class price returns. The lower the correlation coefficient, the greater the diversification benefits which can be attained to the investor. Assets therefore with fairly moderate average returns can therefore have an appeal, and held in an optimal portfolio of financial assets, due to their ability to offset variability in the overall portfolio and hence a reduction in risk, and thus the overall expected volatility of the overall portfolio. We focus on the violin sector as a means of portfolio diversification against a number of alternative financial asset classes.

In Table 2, we provide the summary statistics for a variety of other financial asset classes over the period 1986-2006. In Table 3, the correlation between all these asset classes in the previous 20 years is shown. The correlation between violins

Table 2: Summary statistics

\begin{tabular}{|c|c|c|c|c|c|c|c|c|c|}
\hline Returns & $\begin{array}{l}\text { MSCI } \\
\text { WORLD }\end{array}$ & $\begin{array}{l}\text { MSCI } \\
\text { US }\end{array}$ & $\begin{array}{l}M S C I \\
\text { UK }\end{array}$ & LEHMAN & GSCI & $\begin{array}{l}\text { UK-DS } \\
\text { Real } \\
\text { Estate - }\end{array}$ & $\begin{array}{l}\text { UK } 10 \\
\text { YEAR } \\
\text { GOVT }\end{array}$ & $\overline{A R T}$ & $\begin{array}{l}\text { AMR } \\
\text { Violins }\end{array}$ \\
\hline $\begin{array}{c}\text { Av Annual } \\
\text { Return }\end{array}$ & $9.021 \%$ & $11.217 \%$ & $10.250 \%$ & $9.286 \%$ & $9.263 \%$ & $12.305 \%$ & $9.069 \%$ & $6.581 \%$ & $8.389 \%$ \\
\hline $\begin{array}{c}\text { Annual } \\
\text { Stdev }\end{array}$ & $14.275 \%$ & $15.159 \%$ & $16.329 \%$ & $5.475 \%$ & $18.430 \%$ & $19.830 \%$ & $7.594 \%$ & $8.512 \%$ & $8.686 \%$ \\
\hline Skew & -1.234 & -1.074 & -1.414 & 0.063 & -0.061 & -1.071 & -0.024 & -0.716 & 0.211 \\
\hline Kurt & 4.078 & 4.124 & 7.130 & 0.931 & 0.441 & 4.586 & 1.761 & 3.416 & 1.978 \\
\hline Max return & 0.097 & 0.125 & 0.137 & 0.060 & 0.170 & 0.149 & 0.089 & 0.083 & 0.116 \\
\hline Min return & -0.218 & -0.239 & -0.300 & -0.041 & -0.150 & -0.331 & -0.078 & -0.103 & -0.074 \\
\hline $\begin{array}{l}\text { AvRet } \\
\text { (monthly) }\end{array}$ & $0.75 \%$ & $0.93 \%$ & $0.85 \%$ & $0.77 \%$ & $0.77 \%$ & $1.03 \%$ & $0.76 \%$ & $0.55 \%$ & $0.70 \%$ \\
\hline $\begin{array}{l}\text { Stdev } \\
\text { (monthly) }\end{array}$ & $4.12 \%$ & $4.38 \%$ & $4.71 \%$ & $1.58 \%$ & $5.32 \%$ & $5.72 \%$ & $2.19 \%$ & $2.46 \%$ & $2.51 \%$ \\
\hline
\end{tabular}

Equity indices are from Morgan Stanley Capital Indices for US equity, (MSCI US), UK equity (MSCI UK) and world equity (MSCI World), Lehman Brothers Aggregate Corporate Bond Index (available only for the US) and Datastream Real estate index. We use the UK ten-year Government Bond Index, and UK Government Treasury Bills, which have only been available on a monthly basis from 1980. S\&P GSCI data commodity Future data are available from Goldman Sachs. Data are collected from Datastream, Global Financial Data. All Art Index and General Violin Index is from Art Market Research. 
Table 3: Correlation statistics for violins, fine art and financial markets 1986-2006

\begin{tabular}{|c|c|c|c|c|c|c|c|c|c|}
\hline & $\begin{array}{l}\text { MSCI } \\
\text { WORLD }\end{array}$ & $\begin{array}{l}\text { MSCI } \\
\text { US }\end{array}$ & $\begin{array}{l}\text { MSCI } \\
\text { UK }\end{array}$ & LEHMAN & GSCl & $\begin{array}{l}\text { UK-DS } \\
\text { Real } \\
\text { Estate - }\end{array}$ & $\begin{array}{l}\text { UK } 10 \\
\text { YEAR } \\
\text { GOVT }\end{array}$ & $A R T$ & $\begin{array}{l}\text { AMR } \\
\text { violins }\end{array}$ \\
\hline $\begin{array}{l}\text { MSCl } \\
\text { WORLD }\end{array}$ & 1.000 & & & & & & & & \\
\hline MSCI US & 0.885 & 1.000 & & & & & & & \\
\hline MSCI UK & 0.807 & 0.756 & 1.000 & & & & & & \\
\hline LEHMAN & 0.061 & 0.173 & 0.059 & 1.000 & & & & & \\
\hline $\begin{array}{l}\text { GSCl } \\
\text { Commodity }\end{array}$ & 0.004 & -0.042 & 0.006 & -0.059 & 1.000 & & & & \\
\hline $\begin{array}{l}\text { UK-DS Real } \\
\text { Estate }\end{array}$ & 0.490 & 0.451 & 0.690 & 0.015 & 0.092 & 1.000 & & & \\
\hline $\begin{array}{l}\text { UK } 10 \text { YEAR } \\
\text { GOVT }\end{array}$ & 0.133 & 0.146 & 0.270 & 0.507 & -0.056 & 0.289 & 1.000 & & \\
\hline ART & -0.021 & -0.038 & -0.051 & -0.065 & 0.083 & 0.045 & -0.016 & 1.000 & \\
\hline AMR Violins & -0.029 & -0.002 & -0.074 & 0.077 & 0.094 & -0.115 & 0.077 & 0.002 & 1.000 \\
\hline
\end{tabular}

Equity indices are from Morgan Stanley Capital Indices for US equity, (MSCI US), UK equity (MSCI UK) and world equity (MSCI World), Lehman Brothers Aggregate Corporate Bond Index (available only for the US) and Datastream Real estate index. We use the UK ten-year Government Bond Index, and UK Government Treasury Bills, which have only been available on a monthly basis from 1980. S\&P GSCl data commodity Future data are available from Goldman Sachs. Data are collected from Datastream, Global Financial Data. All Art Index and General Violin Index is from Art Market Research (Central 80 per cent)

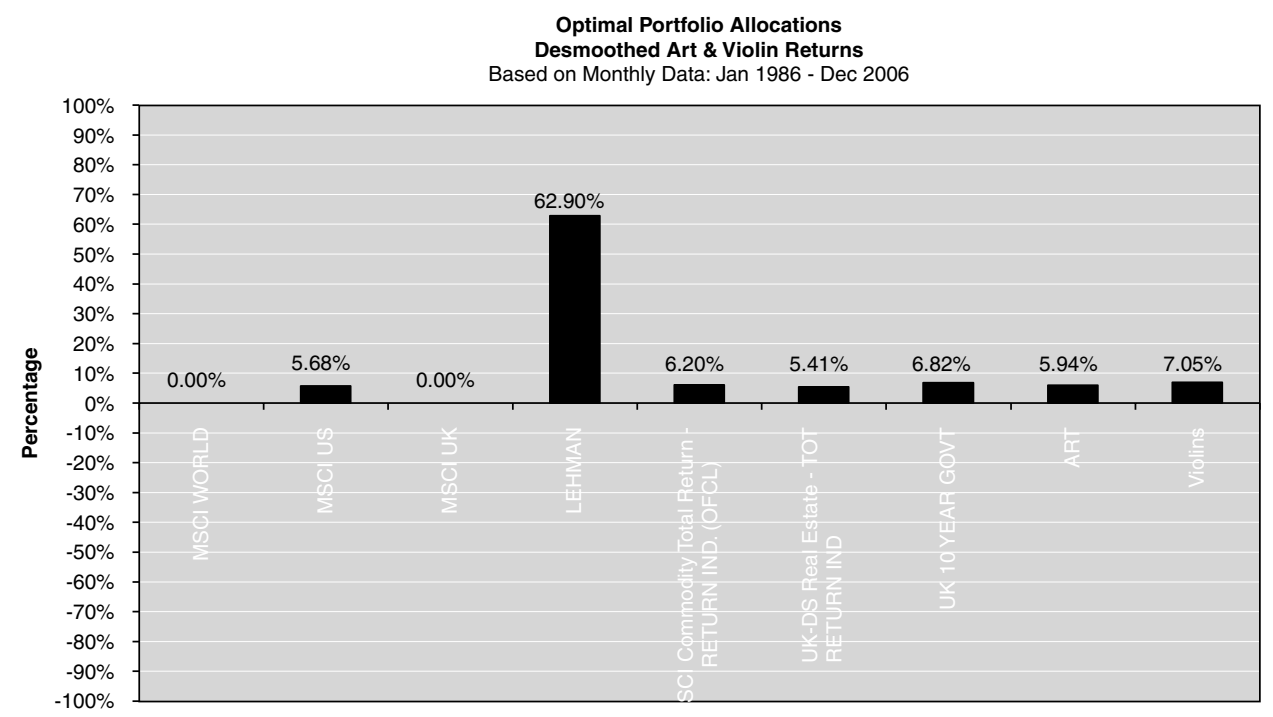

Figure 2: Optimal portfolio allocation including violins: 1986-2006

Equity indices are from Morgan Stanley Capital Indices for US equity, (MSCI US), UK equity (MSCI UK) and world equity (MSCI World), Lehman Brothers Aggregate Corporate Bond Index (available only for the US) and Datastream real estate index for the UK. We use the UK ten-year Government Bond Indices, and UK Government Treasury Bills, which have only been available on a monthly basis from 1980. S\&P GSCl data commodity Future data are available from Goldman Sachs. Data are collected from Datastream, Global Financial Data. All Art Index and the General Violin indices are from Art Market Research.

and other financial asset classes is extremely low. Also with the art market the correlation is very low. It appears that these markets are highly independent from each other, with different factors driving demand and hence prices in these markets. At first glance it would appear that there is some potential diversification benefit available from investing into musical instruments as well as into art.
Using a standard mean-variance optimal portfolio model, we estimate the optimal portfolio that would have led to the highest risk-adjusted returns over the period 1986-2006. The outcome of the optimal portfolio model is of course specific to the input and thus to the historical returns made for the chosen asset classes over this period. If financial returns are used to estimate 
future returns, then we could use the model for an optimal portfolio strategy; however, future returns are by definition unknown, and thus the model only provides the investor of an idea of a diversified portfolio strategy and no guarantee of any future performance.

The outcome of the optimal portfolio strategy is given in Figure 2. We find a low allocation into equities, which given the recent poor performance and the relatively high volatility is not surprising. Corporate bonds have done extremely well in the past 20 years, and hence the model results in a large allocation into this asset which has achieved high annual returns. Interestingly, the model allocates a 6 and a 7 per cent allocation into both art and violins, respectively. Here we have assumed a flat rate 5 per cent point increase in the standard deviation of the series to account for the smoothed data.

\section{Practical implications}

In this section we look at the implications for the pension sector for an investment into the fine violin sector. The pension fund industry is extremely large and the size of the violin sector of the musical instrument market, although growing, is relatively small in comparison. It is therefore implausible for extremely large institutional investors to adapt a strategy of a large investment into fine violins into their investment strategies. More interesting however, is the choice for more tailormade pension solutions to be offered to high net worth clients, who are aiming for a high-risk investment in an alternative asset.

\section{Conclusions}

The continual search to reap higher risk-adjusted returns has led to a number of highly alternative assets to be considered for financial investment purposes. Recently, a number of funds have emerged to indirectly invest into the arts sector. The focus has been on fine art, wine and more recently into the possibility of investing into other collectible items and memorabilia. One such area is musical instruments. In this paper, we take a look at the violin sector in particular, which has shown steady annual growth in market value over the past half century, fuelled by a combination of a shortage in supply at the high end of the market and a continued increase in global demand. Using data collected from auction houses and private dealers, we analyse the risk-return characteristics of the violin sector, and find that the high-end violin sector offers the investor an attractive investment on purely financial terms. The low correlation between violins and other financial asset classes, including art, renders an investment into violins high attractive as part of a diversified portfolio strategy. This is also the case when accounting for the smooth nature of the series, and by desmoothing the data to adjust the volatility to something more in line with the true underlying series. Owing to the smaller scale of the market we would not like to advise institutional investors to participate in such a strategy; however, for the private client, an investment into violins could be an interesting alternative asset to include in the portfolio. Optimal portfolio allocations using empirical returns over the past 20 years provide support for investors to consider an investment into violins as an attractive, albeit small addition to their investment strategy. The results depend crucially on the assumption about the risk involved in such a strategy. The highly illiquid market is a factor that should increase the riskiness to the private investor from such a strategy. Also the presence of only a small number of funds which offer an indirect investment into violins means that there are still a few strings attached when investing into musical instruments.

\section{Acknowledgments}

The author is grateful to Dr Aymeric Kalife of Dauphine University for comments on an earlier draft.

Disclaimer: The views expressed in this paper are the views of the authors only. All errors pertain to the authors. Please ask for the author's permission before reproduction of this paper, in whole or in part.

\section{References and Notes}

1 Ruggiero Ricci, a master violinist was reported to have sold his famed violin for $\$ 3 \mathrm{~m}$ in 1999 , and more recently in 2006 a Stradivarius violin at auction reaching $\$ 3.5 \mathrm{~m}$. 
2 Common reasons for forced sales, such as from debt, death and divorce result in a more representative data sample.

3 Stein, J. P. (1977) 'The monetary appreciation of paintings', Journal of Political Economy, Vol. 85, No. 5, pp. 1021-1035.

4 Goetzman, W. (1992) 'Accounting for taste, art and the financial markets over 3 centuries', AER, Vol. 83, No. 5, pp. 1370-1376.

5 Okunev, J. and White, D. (2003) 'Hedge fund risk factors and value at risk of credit trading strategies', Working Paper, University of New South Wales.

6 Campbell, R. (2008) 'Art as an alternative asset class', Journal of Alternative Investments (forthcoming).

7 See Campbell (2005) for a detailed analysis on desmoothing art series data.

\section{Appendix A}

\section{Constituents in the Florian Leonhard Fine Violins Index}

del Gesu 1743

del Gesu 1738

Strad 1685

Rogeri 1772

Fagnola 1923

Bergonzi 1739

del Gesu 1732

Guadagnini 1765

Strad 1714

del Gesu 1735

F Ruggeri 1885

Strad 1713

Fagnola 1924

Pedrazzini 1928

G Degani 1900

Pedrazzini 1929

E Degani 1896

C F Landolfi 1758

J F Giudantus 1700

N Gagliano 1735

A\&H Amati 1625

Strad 1729

G Cappa 1690

F Gagliano 1780

G F Celoniatus 1730

F Gagliano 1784

Strad1711 sp crack

T Balestrieri 1750

A Gragnani 1770

G F Pressenda 1846

N Gagliano 1750

C A Testore 1760
F Gagliano 1785

A\&H Amati 1635

N Gagliano 1770

G B Guadagnini 1769

E Degani 1899

F Gagliano 1772

G Degani 1898

G Rocca 1852

G F Pressenda 1854

G Gagliano 1800

G Pedrazzini 1928

N Gagliano 1750

G Guarneri 1703

L Storioni 1780

Strad 1696

N Gagliano 1750

G B Rogeri 1670

$\mathrm{T}$ Eberle 1786

G Rocca 1854

G Rocca 1861

N Gagliano 1770

A Amati

N Amati (small pattern)

N Amati (grand pattern)

Ga Antoniazzi

Gr Antoniazzi

L Arcangioli

$\mathrm{T}$ Balestrieri

C Bergonzi

L Bisiach

L\&T Carcassi

G Ceruti

E Degani

G B Gabrielli

A Gagliano

N I Gagliano

G Gagliano

F Gobetti

$M$ Goffriler

G Grancino

G B Guadagnini

A Guarneri (grand)

P Guarneri (Mantua)

P Guarneri (Venice)

$G$ f. A Guarneri

C Landolfi

G P Maggini

D Montagnana 


\author{
V Panorma \\ G F Pressenda \\ G Rivolta \\ G A Rocca \\ E Rocca \\ G B Rogeri \\ F Ruggieri (grand pattern) \\ G Scarampella \\ S Serafin \\ L Storioni \\ D Tecchler (violin) \\ D Tecchler (cello) \\ C G Testore \\ C Tononi \\ L Ventapane \\ G Degani 1897 \\ G B Guadagnini 1744 \\ Strad 1710 (sp crack) \\ Strad 1697 \\ Montagnana 1727 \\ Balestrieri \\ Guadagnini 1750 \\ P Guarneri (Mantua) 1703 \\ N Amati (grand) 1664 \\ G B Gabrielli \\ G B Guaduagnini 1740 \\ J B Vuillaume \\ P Guarneri (Mantua) \\ C F Landolfi (1750)
}

\section{Appendix B}

\section{Constituents in the AMR violin indices}

Antonio and Hieronymus Amati, Romeo

Antoniazzi, Georges Apparut, Job Ardern, William

Atkinson, Paul Bailly, Tommaso Balestrieri,

Benjamin Banks, Bruno Barbieri, Francois Barzoni,
Léon Bernardel, John Betts, Leandro Bisiach, $\mathrm{H}$. Emile Blondelet, Charles Boullangier, James William Briggs, Antonio Capela, Lorenzo \& Tommaso Carcassi, Aristide Cavalli, Georges Adolphe Chanot, Nicolas Augustin Chappuy, Chipot-Vuillaume, Jean Baptiste Colin, Ch.J.-B. Collin-Mézin, Stefano Conia, George Craske, Eugenio Degani, Giulio Degani, Honoré Derazey, Amèdée Dieudonné, Thomas Dodd, Richard Duke, Hannibal Fagnola, Giuseppe Fiorini, William Forster, Ferdinando Gagliano, Joseph Gagliano, Gand \& Bernardel, Jeffery James Gilbert, William Glenister, Goulding \& Co., Antonio Gragnani, Giovanni Grancino, Giovanni Battista Guadagnini, Andrea Guarneri, Matthew Hardie, Hart \& Son, Hawkes \& Son, Thomas Earle Hesketh, Joseph Hill, Lockey Hill, W.E. \& Sons Hill, George Wulme Hudson, John Johnson, Thomas Kennedy, Laberte-Humbert, Antonio Lechi, John Lott, Louis Lowendall, Giuseppe Lucci, Nicolas Lupot, Giovanni Paolo Maggini, Gabriel Magnière, Walter H. Mayson, Emile Mennesson, Domenico Montagnana, Giovanni Battista Morassi, Alfred Moritz, Léon Mougenot, Nicolas Didier Ainé, John William Owen, Vincenzo Panormo, Giuseppe Pedrazzini, Thomas Perry, Perry \& Wilkinson, Claude Pierray, Gaetano Pollastri, Gian Francesco Pressenda, George Pyne, Arthur Richardson, William Robinson, Joseph Rocca, Ernst Heinrich Roth, Francesco Ruggieri, Rushworth \& Dreaper, Vincenzo Sannino, Giovanni Schwarz, Iginio Sderci, Santo Seraphin, Hippolythe Chretien Silvestre, Pierre Silvestre, Pierre \& Hippolyte Silvestre, Alexander Smillie, Thomas Smith, Carlo Storioni, Antonio Stradivari, Carlo Antonio Testore, Charles \& Samuel Thompson, Lorenzo Ventapane, Alfred Vincent, Jean-Baptiste Vuillaume, Peter Walmsley and Emanuel Whitmarsh. 